\title{
PENERBITAN SERTIFIKAT HAK ATAS TANAH PENGGANTI YANG HILANG OLEH BADAN PERTANAHAN NASIONAL
}

\author{
Nur Triaji Antasena \\ Kantor Notaris Ahmad Hidayat \\ Jl. Raya Sladi Kejayan Pasuruan \\ email: triajinotpasmil@gmail.com
}

\begin{abstract}
Abstrak
Hak Milik atas tanah sifatnya turun temurun, dan mempunyai sifat terkuat, namun bagaimana jika sertifikat yang kita miliki hilang, apakah hak kita juga akan hilang. Hal ini akan penulis bahas dalam bagaiman proses penerbitan sertipikat pengganti yang hilang oleh kantor Pertanahan Kabupaten Pasuruan dan Hambatan apa yang terjadi dalam pengurusan sertifikat pengganti tersebut. Hasil penelitian jika sertifikat yang kita miliki tersebut hilang dapat mengajukan permohonan penerbitan sertifikat pengganti oleh Kantor Pertanahan dengan prosedur dan syarat-syarat yang telah ditetapkan oleh peraturan perundang-undangan. Akan tetapi dalam penerbitan sertifikat pengganti banyak kendala yang di hadapi yaitu selain waktunya yang panjang juga keterbatasan suberdaya manusianya dari pihak kantor pertanahan Kabupaten Pasuruan dalam pendaftaran yang serba online yang baru diberlakukan di kantor pertanahan seluruh Indonesia. Jalan keluar adanya pemangkasan prosedur dalam penerbitannya sehingga tidak memerlukan waktu yang panjang dan tidak berbelit belit.
\end{abstract}

Kata Kunci: penerbitan sertipikat pengganti, hilang

\begin{abstract}
Property rights over land are hereditary, and have the strongest nature, but what if the certificate we have is lost, will our rights be lost. This will be discussed by the writer in how the issuance process of the lost certificate by the Pasuruan Regency Land Office and the obstacles that occur in arranging the replacement certificate. The results of the study if the certificate that we have is lost can submit a request for the issuance of a replacement certificate by the Land Office with the procedures and terms set by the legislation. However, in the issuance of substitute certificates there are many obstacles faced, namely in addition to the long time also the limitations of human resources from the land office of Pasuruan Regency in the all-online registration that was only implemented in the land offices throughout Indonesia. The way out is the pruning of procedures in publishing so that it does not require a long time and is not complicated.
\end{abstract}

Keywords: issuance of substitute certificate, lost 


\section{PENDAHULUAN}

Perihal sertifikat pengganti kerena hilang atau rusak termuat dalam Pasal 57 ayat (1) Peraturan Pemerintah Nomor 24Tahun 1997 yang isinya: (1) Atas permohonan pemegang hak diterbitkan sertifikat baru sebagai pengganti sertifikat yang rusak, hilang, masih menggunakan blangko sertifikat yang tidak digunakan lagi, atau yang tidak diserahkan kepada pembeli lelang dalamsuatu lelang eksekusi.

Bardasarkan bunyi pasal diatas memang tidak mudah bagi Kantor Pertanahan begitu saja untuk mengeluarkan sertifikat pengganti atas sebidang tanah yang telah bersertifikat. Ada syarat-syarat yang harus dipenuhi untuk mendapat kembali sertifikat atas tanah tersebut, karena dikhawatirkan adanya sertifikat ganda terhadap sebidang tanah yang sama.

Di dalam menerbitkan sertifikat pengganti, biasanya Kantor Pertanahan akan melakukan peninjauan lokasi (verlap) dan melakukan pengukuran ulang untuk memastikan bahwa keadaan tanah tersebut masih seperti yang tertera dalam buku tanah dan foto copy sertifikat dari pemohon jika masih ada berkas yang terdahulunya.

Badan Pertanahan Nasional dalam hal ini sangat berhati-hati dalam mengeluarkan sertifikat pengganti. Namun bukan suatu masalah yang sangat berat, jika ada pihak yang mengalami kehilangan sertifikat dan ingin mengurus kembali tanahnya untuk memperoleh sertifikat pengganti. Asalkan dia memiliki keinginan yang besar untukmengurus kembali tanahnya, dan mampu membuktikan terlebih dahulu kalau tanahnya tersebut adalah benar-benar haknya, dan memenuhi segala syarat-syarat yang telah ditentukan oleh Undang-Undang.

Berdasarkan uraian itu, maka penulis merumuskan masalah sebagai berikut: 1) penerbitan sertifikat hak atas tanah pengganti yang hilang oleh Kantor Pertanahan Kabupaten Pasuruan dan 2) hambatan dan upaya apa yang dilaksanakan oleh Kantor Pertanahan Kabupaten Pasuruan atas penerbitan sertifikat hak atas tanah pengganti yang hilang?

\section{METODE PENELITIAN}

Penelitian adalah salah satu bentuk komonikasi antara ilmuan. Cara melakukan komonikasi ilmiah yang baik dan cermat tidak akan dapat dikuasai secara tiba-tiba, diperlukan latihan secara sistematis disertai penguasaan ilmu yang tepat. ${ }^{1}$ Dalam penelitian ini jenis yang digunakan adalah yuridis empiris. Dan pendekatan yang digunakan dalam penelitian adalah pendekatan yuridis sosiologis. Pendekatan yuridis sosiologis adalah mengidentifikasi dan mengkonsepsikan hukum sebagai institusi sosial yang

\footnotetext{
${ }^{1}$ Sukandarrumidi, Metodologi Penelitian: Petunjuk Praktis untuk Peneliti Pemula,
} (Yogyakarta: Gajah Mada University Press,2006), hal. 26-30. 
sosiologis dan fungsional dalam sistem kehidupan nyata. ${ }^{2}$ Jenis data yang digunakan dalam penelitian ini adalah jenis data primer dan sekunder. Data primer adalah data yang diperoleh secara langsung dari sumber pertama yang berkaitan dengan permasalahan yang akan dibahas. Data sekunder adalah data-data yang diperoleh dari buku-buku sebagai data pelengkap sumber data primer. Sumber data sekunder penelitian ini adalah data-data yang diperoleh dengan melakukan kajian pustaka seperti buku-buku ilmiah, peraturan perundang-undangan, hasil penelitian dan sebagainya.Dalam penelitian ini penulis akan menggunakan teknik analisis kualitatif adalah sumber data yang disuguhkan dalam bentuk dua parameter "abstrak", misalnya: banyak-sedikit, tinggi-rendah, tua-muda, panas-dingin, labanirlaba. $^{3}$

\section{PEMBAHASAN}

Pengertian sertifikat terdapat di dalam Peraturan Pemerintah Nomer 24 Tahun 1997 tentang pendaftaran tanah pasal 31 ayat (1) yang berbunyi sebagai berikut: sertifikat merupakan surat tanda bukti hak yang berlaku sebagai alat pembuktianyang kuat mengenai data fisik dan data yuridis yang termuat didalamnya,sepanjang data fisik dan data yuridis tersebut sesuai dengan data yang ada dalamsurat ukur dan buku tanah hak yang bersangkutan. Selanjutnya pengertian sertifikat terdapat dalam Bab I Ketentuan Umum pasal 1 poin 3 yang menyatakan sertifikat adalah tanda bukti hak yang dimaksud dalam Pasal 19 Undang-undang Pokok Agraria. Adapun pengertian sertifikat dalam PP No. 24 Tahun 1997 tentang Pendaftaran Tanah Pasal 32 ayat (1) dan (2) yang berbunyi, bahwa sertifikat adalahmerupakan surat tanda bukti hak yang berlaku sebagai alatpembuktian yang kuat mengenai data fisik dan data yuridis yang termuat didalamnya, sepanjang data fisik dan data yuridis tersebut sesuai dengan datayang ada dalam surat ukur dan buku tanah hak yang bersangkutan.

\section{Penerbitan Sertifikat Hak Atas Tanah Pengganti Yang Hilang Oleh Kantor Pertanahan Kabupaten Pasuruan}

Penerbitan atau prosedur sertifikat hak atas tanah pengganti yang hilang oleh Kantor Pertanahan di Kabupaten Pasuruan, haruslah sesuai dengan aturan yang berlaku. Akan tetapi dalam hal penerbitan sertifikat pengganti telah di atur oleh peraturan perundang-undangan seperti yang telah penulis uraikan di atas, yaitu di atur dalam pasal 57 ayat (1) Peraturan

${ }^{2}$ Soerjono Soekanto, Pengantar Penelitian Hukum, (Jakarta: Universitas Indonesia Press, 1986), hal.51.

${ }^{3}$ Sukandarrumidi, Op.Cit, hal, 45-47. 
Pemerintah nomer 24 tahun 1997 yang menyatakan bahwa atas permohonan pemegang hak diterbitkan sertifikat baru sebagai pengganti sertifikat yang rusak, hilang, masih menggunakan blanko sertifikat yang tidak digunakan lagi, atau yang tidak diserahkan kepada pembeli lelang dalam suatulelang eksekusi.

Dalam Peraturan Pemerintah Nomor 24 Tahun 1997 tentang Pendaftaran Tanah pasal 138 yang berbunyi sebagi berikut:

a) Penerbitan sertifikat pengganti karena hilang didasarkan atas pernyataan dari pemegang hak mengenai hilangnya sertifikat.

b) Pernyataan tersebut dibuat dibawah sumpah di depan Kepala Kantor Pertanahan letak tanah yang bersangkutan atau Kepala Seksi Pengukuran dan Pendaftaran Tanah atau pejabat lain yang ditunjuk Kepala Kantor Pertanahan.

Serta dalam Keputusan Menteri Agraria/Kepala Badan Pertanahan Nasional Nomor 10 Tahun 1993 (KepmenAgraria No.10/1993) Pasal 1 huruf d, menyatakan bahwa Penggantian sertifikat adalahpenggantian sertifikat lama dengan sertifikat baru.

Adapun prosedur yang harus dilalui di dalam penerbitan sertifikat yang hilang di kantor Pertanahan Kabupaten Pasuruan adalah sebagai berikut :

\section{a. Surat Tanda Lapor Kehilangan Dari Kepolisian Setempat}

Langkah pertama yang harus Anda lakukan adalah melaporkan perihal kehilangan sertifikat tanah Anda tersebut ke pihak yang berwenang, dalam hal ini kepolisian. Di sejumlah wilayah, laporan ke Polsek sudah cukup, namun ada wilayah yang mengharuskan minimal laporan ke Polres. Saat melapor, sebutkan nomor sertifikat, lokasi tanah, dan atas nama siapa tanah tersebut.Petugas kepolisian akan memeriksa kelengkapan berkas laporan. Biasanya petugas akan meminta surat pengantar dari kelurahan setempat sebagai dasar laporan. Pihak kepolisian juga mungkin mensyaratkan agar kehilangan sertifikat tersebut diumumkan di media cetak lokal dan nasional serta media elektronik. Akan tetapi langkah pemasangan pengumuman ini biasanya dilakukan oleh Kantor pertanahan, atas biaya pemohon.Setelah itu akan dikeluarkan Berita Acara Pemeriksaan (BAP) yang nantinya dibawa ke Kantor pertanahan setempat.

\section{b. Pemblokiran Sertifikat Tanah}

Jika terdapat jeda waktu yang cukup lama antara kejadian hilangnya sertifikat tanah dengan keluarnya BAP sebagai dasar pemblokiran sertifikat, misalnya lebih dari 1 bulan, hal ini dapat diatasi dengan langsung mengirimkan surat permohonan pemblokiran sertifikat tanah ke Kantor 
pertanahan setempat pada saat sertifikat diketahui hilang dengan menceritakan kronologi kejadian.Untuk memblokir sertifikat tanah, juga diperlukan dokumen seperti fotokopi sertifikat tanah yang dimaksud serta identitas pemilik sertifikat untuk melengkapi surat blokir yang ditujukan kepada Kepala Kantor Pertanahan setempat.Setelah surat blokir sudah diterima pihak Kantor Pertanahan dan sudah dicatatkan di buku tanah, maka sertifikat tanah Anda pun sudah aman, tidak ada pihak lain yang dapat melakukan proses apa pun terhadap tanah Anda hingga ada permohonan sertifikat pengganti.

\section{c. Mengurus Penggantian Sertifikat Tanah ke Kantor Badan Pertanahan Nasional (BPN)}

Setelah membuat surat keterangan kehilangan sertifikat tanah di Kantor Polisi, BAP tersebut di bawa ke kantor pertanahan setempat untuk di tindak lanjuti atas permintaan penerbitan sertifikat.

\section{d. Permohonan}

Permohonan dilakukan oleh pemegang hak. Di dalam Peraturan Pemerintah Nomor 24 Tahun 1997tentang Pendaftaran Tanah (PP 24/1997) Pasal 57 ayat (1) dinyatakan bahwa:

1) Atas permohonan pemegang hak diterbitkan sertifikat baru sebagai pengganti sertifikat yang rusak,hilang, masih menggunakan blangko sertifikat yang tidak digunakan lagi, atau yang tidak diserahkankepada pembeli lelang dalam suatu lelang eksekusi.

2) Permohonan sertifikat pengganti sebagaimana dimaksud pada ayat (1) hanya dapat diajukan oleh pihak yang namanya tercantum sebagai pemegang hak dalam buku tanah yang bersangkutan atau pihaklain yang merupakan penerima hak berdasarkan akta PPAT atau kutipan risalah lelang sebagaimana dimaksud dalam Pasal 37 dan Pasal 41, atau akta sebagaimana dimaksud Pasal 43 ayat (1), atau surat sebagaimana dimaksud Pasal 53, atau kuasanya."

Melampirkan sertifikat rusak yang bersangkutan sebagaimana bunyi Pasal 137 ayat (1) Permen Agraria3/1997, bahwa permohonan penerbitan sertifikat pengganti karena rusak atau karena masih menggunakan blangko sertifikat lama dapat diajukan oleh yang berkepentingan dengan melampirkan sertifikat atau sisa sertifikat yang bersangkutan.

\section{e. Pemeriksaan Atau Verifikasi Oleh BPN}

Pemeriksaan atau Verifikasi oleh Kantor Pertanahan sesuai dengan isi Pasal 3 Kepmen Agraria 10/1993 yang berbunyi bahwa dalam melaksanakan penggantian sertifikat, Kepala Kantor Pertanahan wajib memeriksa sertifikat lamayang bersangkutan, dengan mencocokkannya terhadap buku tanah, surat ukur/gambar situasi, peta-peta, warkah dan 
daftar-daftar isian lain yang bersangkutan dengan sertifikat tersebut yang ada padaKantor Pertanahan yang bersangkutan.

\section{f. Terkait Surat Ukur/Gambar Situasi}

Terkait Surat Ukur/Gambar Situasi Berlaku ketentuan sesuai dengan isi Pasal $5 \mathrm{~K}$

1) Dalam penggantian sertifikat lama yang sudah ada Surat Ukur/Gambar Situasinya, tidak perludilakukan pengukuran, pemetaan danpembuatan Surat Ukur/Gambar Situasi yang baru, sepanjang SuratUkur/Gambar Situasi yang lama masih memenuhi syarat teknis

2) Surat Ukur/Gambar Situasi yang merupakan bagian sertifikat baru adalah Salinan dari SuratUkur/Gambar Situasi lama yang dibuat pada blangko Surat Ukur/Gambar Situasi baru dan diberi nomoryang baru."

Artinya dokumen yang dimaksud, sepanjang masih memenuhi syarat teknis, maka tidak perlu pembuatansurat ukur/gambar situasi ulang, begitu juga sebaliknya.

\section{g. Penggantian Sertifikat Dicatat Pada Buku Tanah Yang Bersangkutan}

Penggantian sertifikat dic tat pada buku tanah yang bersangkutan Pasal 57 ayat (4) PP 24/1997 berbunyi (4) Penggantian sertifikat sebagaimana dimaksud pada ayat (1) dicatat pada buku tanah yangbersangkutan.

Dengan catatan bahwa sertifikat yang lama ditahan dan dimusnahkan, sesuai dengan isi Pasal 58 PP24/1997, bahwa dalam hal penggantian sertifikat karena rusak atau pembaharuan blangko sertifikat, sertifikat yang lama ditahan dan dimusnahkan.

\section{h. Penerbitan Sertifikat Pengganti}

Berlaku ketentuan Pasal 139 PermenAgraria 3/1997, bahwa perubahan nomor sertifikat yang lama (rusak)dengan sertifikat yang baru (pengganti).Apabila dalam jangka waktu satu bulan atau 30 hari sejak pemasangan pengumuman di media cetak tidak ada pihak yang mengajukan keberatan atas pembuatan sertifikat pengganti, atau ada pihak yang mengajukan keberatan namun keberatannya terbukti tidak beralasan atau tidak mendasar, maka Kantor Pertanahan akan menerbitkan sertifikat pengganti.

\section{i. Waktu Yang Diperlukan}

Berdasarkan peraturan-peraturan terkait yang ada, tidak ada batasan waktu yang tegas terkait berapalama waktu yang dibutuhkan dalam proses penggantian sertifikat, dimulai sejak permohonan sampaidengan 
penerbitan. Informasi bahwa waktu proses pengurusansertifikat yang hilang adalahsekitar 2 sampai 3 bulan.

Setelah semuanya dilalui maka, selanjutnya dimasukkan ke kantor Pertanahan Kabupaten Pasuruan dengan langkah sebagai berikut :

1. Syarat-syarat yang telah dipenuhi oleh pemohon sertifikat pengganti hak atas tanahmaka pemohon dapat mengajukan permohonan penerbitan sertifikat pengganti hakatas tanah di kantor Pertanahan Kabupaten Pasuruan.

2. Pemohon sertifikat pengganti hak atas tanah datang ke KantorPertanahanKabupaten Pasuruan dengan membawa dokumen-dokumen yang telah dijelaskanpada poin persyaratan tersebut diatas, lalu diserahkan keloket II (petugasteknis).

3. Petugas teknis di loket II akan melakukan penelitian terhadap dokumen-dokumen, dan apabila sudah lengkap akan diberikan tanda terimadokumen.

4. Setelah dokumen dibukukan akan diteruskan kekasubsi Pendaftaran Hak

5. KasubsiPendaftaranHakakanmempelajari,mendisposisikandan menyerahkan kepada petugas pelaksana.

6. Dan selanjutnya petugas pelaksana membuat konsep pengumumanberdasarkandokumen-

dokumendarisubseksipendaftaranhak,dandiserahkan kembali ke kasubsi pendaftaran hak.

7. Selanjutnya setelah meneliti kasubsi pendaftaran hak memaraf ataskonseppengumuman tersebut dan diserahkan kepada seksi survei, pengukuran danpemetaan.

8. Selanjutnya kepala seksi survei, pengukuran dan pemetaan, meneliti ataskonsep pengumuman tersebut dan memberikan paraf, kemudian selanjutnyadikirim kepada kepala kantor.

9. Setelah diteliti oleh kepala kantor, kepala kantor menandatangani konseppengumuman tersebut, kemudian konsep pengumuman tersebutdiumumkanpada media masa setempat, kantor kelurahan, dan pada kantor pertanahan itusendiri. Dan apabila dalam jangka waktu 30 hari kerja pengumuman tersebutada yang konplin (keberatan) atau ada yang mengaku dirinya yang mempunyai hak atas tanahtersebut, dan alasan tersebut cukup beralasan setelah diteliti dilapangan olehpetugas kantor pertanahan, makapermohonan sertifikat pengganti tersebutditunda sampai ada 
penyelesaian melalui putusan pengadilan negeri setempat. ${ }^{4}$ Dan jika dalam jangka waktu 30 hari kerja tidak ada yang mengajukankeberatan atas pengumuman penerbitan sertifikat pengganti hak atas tanahmaka Kantor Badan Pertanahan dapat melanjutkan pembuatan sertifikatpengganti hak atas tanah tersebut melalui petugas pelaksana. ${ }^{5}$

10. Petugas pelaksana akan melakukan pinjaman warkah asli, kemudian menelitiwarkah, membuat konsep, salinan surat ukur, membuat sertifikat baru,membuat berita acara, membuat catatan pada buku tanah dan dokumen-dokumen tersebut lalu diserahkan kepada kasubsi pendaftaran hak.

11. Kasubsi pendaftaran hak meneliti dan memberi paraf pada konsep sertifikat,buku tanah, berita acara dan salinan surat ukur, kemudian dokumen-dokumentersebut diserahkan kepada seksi survei, pengukuran dan pemetaan.

12. Kepala seksi survei, pengukuran dan pemetaan memberikan paraf padakonsep sertifikat, buku tanah dan salinan surat ukur/gambar situasi, kemudiandokumen tersebut diserahkan kepada kepala kantor.

13. Kepala kantor memberi tandatangan pada sertifikat, buku tanah, berita acaradan salinan surat ukur/gambar situasi.

14. Kemudian petugas pelaksana akan melakukan pembukuan dan dokumen-dokumen tersebut akan dikirim keloket IV (petugas tata usaha) dan mencatatpada buku khusus penerimaan sertifikat, lalu memberikan sertifikatpengganti hak atas tanah tersebut kepada pemohon atau orang yang diberikankuasa oleh pemohon.

Demikianlah syarat-syarat, prosedur dan langkah-langkah yang harus di jalani oleh pemohon dalam rangka penerbitan sertifikat pengganti karena hilang oleh Kantor Pertanahan Kabupaten Pasuruan sampai dengan terbitnya sertifikat pengganti oleh pemohon.

Setelah prosedur yang dilalaui semuanya maka, akan terbitlah sertifikat pengganti yang secara hukum kekuatan dari serifikat pengganti ini tidak berbeda dengan serifikat pada umumnya.

Penerbitan sertifikat pengganti harus mengandung 3 (tiga) yaitu sebagai berikut:

${ }^{4}$ Wawancara dengan Warinius Kogoyar SH. Sub Seksi Penetapan Hak dan Pemberdayaan Masyarakat Pada tanggal 25 Januari 2019 Jam 09.00 WIB di Kantor Pertanahan Kabupaten Pasuruan .

${ }^{5}$ Wawancara dengan Selamet Wahypono. Sub Seksi Pemeliharaan Hak Tanah Dan pembinaan PPAT pada tanggal 21 Januari 2019 jam 10.00 WIB di Kantor Pertahan Kabupaten Pasuruan 
(1) Asas Kepastian Hukum (Rechtmatigheid). Asas ini meninjau dari sudut yuridis.

Dalam penerbitan sertifikat pengganti yang hilang oleh Kantor Pertanahan Kabupaten Pasuruan adalah ingin memberikan kepastian secara hukum bahwa tanah yang diterbitkan sertifikat pengganti tersebut adalah secara hukum adalah milik pemohon. Yang dibuktikan baik secara yuridis bisa dipertanggung jawabkan dihadapan hukum bahwa sertifikat tersebut adalah syah milik pemohon hal tersebut harus dibuktikan dilapangan dengan mengecek langsung fisik yang ada. Hal ini harus sesui dengan Pasal 32 ayat (1) Peraturan Pemerintah Nomor 24 tahun 1997 yang isinya :"Sertifikat merupakan surat tanda bukti hak yang berlaku sebagai alat pembuktian yang kuat mengenai data fisik dan data yuridis yang termuat didalamnya, sepanjang data fisik dan data yuridis tersebut sesuai dengan data yang ada dalam surat ukur dan buku tanah yang bersangkutan." Dalam hal yang berkenaan kepastian hukum dalam penerbitan sertifikat pengganti harus sesuai dengan pasal 19 UUPA yang menyatakan bahwa :

1. Untuk menjamin kepastian hukum oleh Pemerintah diadakanpendaftaran tanah diseluruh wilayah Republik Indonesia menurutketentuan-ketentuan yang diatur dengan peraturan pemerintah

2. Pendaftaran tersebut dalam ayat (1) Pasal ini meliputi:

a. Pengukuran, perpetaan, dan pembukuan tanah;

b. Pendaftaran hak-hak atas tanah dan peralihan hak-hak tersebut;

c. Pemberian surat-surat tanda bukti hak, yang berlaku sebagai alat

d. Pembuktian yang kuat.

3. Pendaftaran tanah diselenggarakan dengan mengingat keadaan Negaradan masyarakat, keperluan lalu lintas sosial ekonomi sertakemungkinan penyelenggaraannya, menurut pertimbangan MenteriAgraria.

4. Dalam Peraturan Pemerintah diatur biaya-biaya yang bersangkutandengan pendaftaran termasuk dalam ayat (1) di atas, dengan ketentuanbahwa rakyat tidak mampu dibebaskan dari pembayaran biaya-biayatersebut.

(2) Asas keadilan hukum (gerectigheit). Asas ini meninjau dari sudut filosofis, dimana keadilan adalah kesamaan hak untuk semua orang di depan pengadilan. 
Artinya bahwa kalau kita kaitkan dengan penertbitan sertifikat pengganti karena hilang, maka dalam prosedurnya harus diumumkan telebih dahulu sebelum penerbitan sertifikat penggantinya baik melalui media massa maupun melalui papan pengumuman dikelurahan tempat di mana sertikat tersebut itu hilang serta ditempel di papan pengumuman di kantor pertanahan Kabupaten Pasuruan, jika dalam 30 hari tidak ada yang keberatan maka akan diterbitkan sertifikat penggantinya, akan tetapi jika ada pihak yang keberatan dengan sertifikat tersebut, baik pihak Bank yang menyatakan bahwa sertifikat tersebut masih di Bank tapi dinyatakan hilang, atau memang betul hilang tapi ada pihak lain yang menyatakan bahwa sertifikat tersebut adalah miliknya, maka penerbitan sertifikat pengganti tersebut akan di tunda sampai adanya keputusan pengadilan siap yang berhak atas tanah tersebut. Hal ini sesuai dengan teori kepastian hukum karena siapapun yang mengalami seperti hal tersebut baik itu pejabat maupun tidak maka harus mendapatkan perlakuan yang sama dan prosedur yang sama sesuai dengan setandart operasional (SOP).

(3) Asas kemanfaatan hukum (zwechmatigheid atau doelmatigheid atau utility).

Kalau kita kaitkan dengan penerbitan sertifikat pengganti karena hilang oleh kantor pertanahan Kabupaten Pasuruan adalah mempunyai manfaat secara hukum artinya bahwa penerbitan sertifikat pengganti selain mempunya tujuan untuk mempunyai kepastian hukum juga mempunyai manfaat buat pemegang sertifikat tersebut yaitu sebagai bukti kepemilikan atas suatu hak atas tanah. Dengan demikan dengan adanya prosedur penerbitan sertifikat pengganti karena hilang maka membawa manfaat buat orang yang mempunyai hak sehingga tidak menimbulkan hilangnya hak seseorang di mata hukum dan mempunyai kepastian hukum.

Penerbitan sertikat pengganti kalau kita analisis dari sisi pembuktiannya, maka suatu hak apapun harus bisa dibuktikan dan dipertanggung jawabkan. Hal ini akan berkenaan dengan kepastian kepemilikan akan suatu hak.

Menurut Sudikno Mertokusumo menggunakan istilah membuktikan, dengan memberikan pengertian, sebagai berikut: ${ }^{6}$

${ }^{6}$ Andi Sofyan, Hukum Acara Pidana Suatu Pengantar, Yogyakarta, Kencana,2014, hlm, 242. 
a) Kata membuktikan dalam arti logis, artinya memberi kepastian yang bersifat mutlak, karena berlaku bagi setiap orang dan tidak memungkinkan adanya bukti-bukti lain.

Artinya bahwa dalam prosedur penerbitan sertifikat pengganti karena hilang di kantor pertanahan Kabupaten Pasuruan haruslah sesuai dengan bukti-bukti secara yuridis dan pengecekan dilapangan baik dengan pengukuran ulang atau dengan bukti-bukti yang lain yang menyatakan bahwa sertifikat tersebut adalah hak milik pemohon.

b) Kata membuktikan dalam arti konvensional, yaitu pembuktian yang memberikan kepastian, hanya saja bukan kepastian mutlak melainkan kepastian yang nisbi atau relatif, sifatnya yang mempunyai tingkatan- tingkatan:

1. Kepastian yang didasarkan atas perasaan belaka, maka kepastian ini bersifat intuitif dan disebut conviction intime.

2. Kepastian yang didasarkan atas pertimbangan akal, maka disebut conviction raisonnee.

3. Kata membuktikan dalam arti yuridis, yaitu pembuktian yang memberi kepastian kepada hakim tentang kebenaran suatu peristiwa yang terjadi.

Dalam penerbitan sertifikat pengganti di kantor pertanahan Kabupaten Pasuruar putusan pengadilan.

Dari hasil penelitian penerbitan sertifikat pengganti karena hilang oleh kantor pertanahan Kabupaten Pasuruan dan di analisis dengan teori kepastian hukum serta teori pembuktiana, dapat di tarik suatu kesimpulan bahwa dalam penerbitan sertifikat pengganti harus memenuhi persyaratandan melalui prosedur yang ditetapkan peraturan perundangundangan yang berlaku, hal ini menjadi penting karena berkenaan kepastian hukum atas suatu hak seseorang dalam kepemilikan hak atas tanah yang harus dibuktikan baik sercara yuridis maupun secara faktual dilapangan akan tetapi pihak pemohon pada dasarnya tetap dirugikan baik secara materi maupun secara waktu pemohon dirugikan.

\section{Hambatan Dan Upaya Apa Yang Dilaksanakan Oleh Kantor Pertanahan Kabupaten Pasuruan Atas Penerbitan Sertifikat Hak Atas Tanah Pengganti Yang Hilang}

Hambatan yang dialami oleh pemohon dalam pengurusan sertifikat pengganti di Kabupaten Pasuruan penulis membagi 2 bagian yaitu sebagai berikut;

1. Hambatan dari pihak kantor Pertanahan Kabupaten Pasuruan antara lain sebagai berikut : 
a) Kurangnya sumber daya manusia (SDM). Dalam hal ini tenaga ahlidi bidang pertanahan, yang menangani perihal penggantian sertifikat pengganti mulai dari seksi survei, pengukuran danpemetaan sangatlah minim. Yang dalam pelaksanaanya ini banyak dibutuhkan tenaga ahli yang sesuai bidangnya karena volume pekerjaan dalam bidang tersebut selalu meningkat. Diharapkan keseimbangan antara jumlah tenagaahli dengan tugas yang harus diselesaikan sehingga dapat mempercepat proses penertiban sertifikat pengganti atas tanah.

b) Setiap tahunnya Kantor Pertanahan Kabupaten Pasuruan selalu meninggalkan berkas-berkas permohonan yang belum diselesaikan karena pengurusan sertifikat pengganti karena hilang membutuhkan waktu yang agak lama ketimbang pengurusan sertifikat lainnya sehingga menyebabkan menumpuknya tugas yang tidak terselesaikan. Dan menjadi hutang pekerjaan buat tahun berikutnya. Padahal secara teori penerbitan sertifikat pengganti karena hilang hanya membutuhkan waktu 3 bulan.

c) Serta kurangnya koordinasi antara pemohon hak dan Kantor Pertanahan Kabupaten Pasuruan dalam menentukan waktu untu melaksanakan proses pengukuran kembali dan penetapan batasbatas bidang tanah, sehingga dapat menghambat dalamproses penerbitan sertifikat pengganti hak atas tanah.

2. Adapun Faktor Penghambat Dari Pihak Pemohon tentang proses dan prosedur permohonan penggantian sertifikat pengganti adalah sebagai berikut :

a) Masih kurangnya pemahaman masyarakat terhadap prosedur pelaksanaan permohonan pengajuan penggantian sertifikat pengganti karena hilang karena tidak adanya papan petunjuk yang pasti, sehingga menjadi penghambat.

b) Tidak adanya partisipasi pegawai Kantor Pertanahan Kabupaten Pasuruan dalam membantu pemohon, khususnya pemohon yang tak tahu melacak berkas melalui pin (kode) dengan sistemkomputerisasi. Hal ini dikarenakan kurangnya atau kelemahan pengawai dalam tehnologi komputerisasasi yang sekarang serba online.

c) Waktu yang diperlukan dalam pengurusan sertifikat yang hilang oleh Kantor Pertanahan Kabupaten Pasuruan sangatlah panjang dan membutuhkan bianya yang tidak sedikit.

Demikianlah penulis merumuskan hambatan yang di temui dilapangan dalam pengurusan sertifikat pengganti karena hilang oleh Kantor Pertanahan Kabupaten Pasuruan.Dan adapun upaya yang dilakukan oleh 
Kantor Pertanahan Kabupaten Pasuruan dalam hal tersebut, mengarahkan semua pengawai dari Kantor Pertanahan Kabupaten Pasuruan agar belajar komputerisasi yang baru ditetapkan oleh Kantor Badan Pertanahan BPN pusat dalam hal peralihan dan pendaftaran hak atas tanah secara online.

\section{KESIMPULAN}

Prosedur dalam penerbitan sertifikat pengganti karena hilang oleh Kantor Pertanahan Kabupaten Pasuruan adalah memakai peraturan perundang-undangan yang mengatur tentang sertifikat yang hilang oleh pemohon karena antara prosedur sertifikat yang hilang pemohon dengan prosedur penerbitan sertifikat pengganti karena hilang oleh Kantor Pertanahan Kabupaten Pasuruan adalah sama dan tidak ada bedanya. Sehingga Kantor Pertanahan secara moril juga bertanggung jawab atas hilangnya suatu surat kepemilikan seseorang sampai terbit kembali sertifikat penggantinya, sehingga pemegang secara hukum mempunyai kepastian dalam kepemilikan haknya tersebut. Akan tetapi secara ekonomis pihak pemohon merasa dirugikan karena nantinya jika tanah tersebut di jual maka akan jatuh harganya karena dalam sertifikat tersebut ada tulisan sertifikat pengganti.

Adapun hambatan dalam pengurusan sertifikat pengganti karena hilang oleh Kantor Pertanahan Kabupaten Pasuruan adalah selain kurangnya tenaga ahli di bidang tersebut, kurangnya SDM yang menguasai tehnologi komputerisasi, dan waktu yang dibutuhkan terlalu lama.

\section{DAFTAR PUSTAKA}

\section{Buku}

Sukandarrumidi, 2006, Metodologi Penelitian: Petunjuk Praktis untuk

Peneliti Pemula, Yogyakarta: Gajah Mada University Press.

Soerjono Soekanto, 1986, Pengantar Penelitian Hukum, Jakarta: Universitas Indonesia Press.

Andi Sofyan, 2014, Hukum Acara Pidana Suatu Pengantar, Yogyakarta: Kencana.

\section{Peraturan Perundang Undangan}

Undang-Undang Pokok Agraria Nomor 5 Tahun 1960

Undang-Undang Nomor 4 Tahun 1996, tentang HakTanah Beserta BendaBenda yang Berkaitan dengan TanahTanggungan Atas tanah

Peraturan Pemerintah Nomor 24 Tahun 1997 tentang Pendaftaran Tanah 
PENERBITAN SERTIFIKAT HAK ATAS TANAH PENGGANTI YANG HILANG

OLEH BADAN PERTANAHAN NASIONAL (Nur Triaji Antasena)

Peraturan Menteri Negara Agraria atau Kepala Badan PertanahanNasional

Nomor 3 Tahun 1997 tentang Ketentuan PelaksanaanPeraturan Pemerintah Nomor 24 Tahun 1997

Peraturan Menteri Negara Agraria/Kepala BPN No.3 Tahun 1999 tentang Pelimpahan Kewengan Pemberian dan Pembatalan Keputusan Pemberian Hak Atas Tanah. 